\title{
ARTIKELEN
}

\section{Wetenschappelijk onderzoek na overlijden: goed geregeld?*}

\author{
Mr. dr. M.C. Ploem \& Prof. mr. J.C.J. Dute
}

\section{Inleiding}

In 2013 verscheen een artikel in de NRC waarvan de conclusie luidde dat onderzoekers met cellen en weefsels van overleden patiënten (en met de informatie die hieruit naar voren komt) zo ongeveer alles kunnen doen. ${ }^{1}$ Aanleiding voor het stuk vormde de veelbeschreven casus van de onsterfelijke cellen van Henrietta Lacks (de zogenoemde 'HeLa-cellen'). ${ }^{2}$ $\mathrm{Na}$ haar overlijden in 1951 (ten gevolge van baarmoederhalskanker) gingen haar cellen de hele wereld over, en tot op de dag van vandaag worden deze voor onderzoek benut. De zaak kwam in opspraak omdat er voor het gebruik van de cellen (afkomstig uit een stukje tumorweefsel dat enkele maanden voor haar overlijden was afgenomen) aan haar noch haar familieleden toestemming was gevraagd.

Research na overlijden beperkt zich overigens niet tot analyse van cellen, ook weefsels en organen worden onder de loep genomen. Men denke bijvoorbeeld aan onderzoek met hersenweefsel ter bestudering van neurologische en psychiatrische ziekten. Bij uitzondering wordt zelfs het hele lichaam wetenschappelijk onderzocht, bijvoorbeeld om meer te weten te komen over het ontbindingsproces van een lijk.

Zijn cellen en weefsels van overledenen inderdaad vogelvrij, zoals de schrijver van het NRC-artikel suggereert? Die conclusie gaat in elk geval voor Nederland niet op: ons recht stelt aan het gebruik van - eerder in het kader van de hulpverlening afgenomen (en gearchiveerde) - lichaamsmaterialen en gegevens van overledenen bepaalde grenzen. Maar daarmee is niet gezegd dat wetenschappelijk onderzoek na de dood goed geregeld is. Daarover gaat deze bijdrage.

Om de juridische context van medisch-wetenschappelijk onderzoek na overlijden goed in beeld te brengen, maken we onderscheid tussen de situatie waarin het onderzoek wordt uitgevoerd met lichaamsmateriaal en gegevens die vóór het overlijden al beschikbaar waren (en in een PA-archief, medisch dossier of andere opslagplaats of database worden bewaard) en de situatie waarin het onderzoek wordt uitgevoerd met lichaamsmateriaal en gegevens die ná het overlijden vrijkomen, bijvoorbeeld via een op de overledene uitgevoerde obductie of een ontleding van het lijk ten behoeve van onderwijs of wetenschap. In

* Dit artikel is via peer review beoordeeld door twee vakgenoten en geschikt geacht voor publicatie in dit tijdschrift.

** Corrette Ploem is onderzoeker/ docent gezondheidsrecht bij het AMC/Universiteit van Amsterdam, en lid van de redactie van dit tijdschrift. Jos Dute is hoogleraar gezondheidsrecht aan de Radboud Universiteit te Nijmegen, en lid van de redactie van dit tijdschrift.

1 Lucas Brouwers, 'Een mensencel is vogelvrij', NRC Handelsblad 27 april 2013.

2 R. Skloot, The immortal life of Henrietta Lacks, Danvers: The Crown Publishing Group 2011. 
de eerste situatie hebben onderzoekers (met name) te maken met bepalingen van het Burgerlijk Wetboek inzake de geneeskundige behandelingsovereenkomst (WGBO), in de tweede situatie met die van de Wet op de lijkbezorging (Wlb). ${ }^{3}$

De opzet van deze bijdrage is als volgt. In paragraaf 2 brengen we het juridische kader voor wetenschappelijk onderzoek na overlijden van de patiënt in beeld. We besteden niet alleen aandacht aan de inhoud ervan, maar gaan ook in op de knelpunten. ${ }^{4}$ In paragraaf 3 reflecteren we hierop: vertoont het geheel van regels belangrijke lacunes? Biedt het een evenwichtige afweging van het belang van de privacy enerzijds en het belang van de vrije wetenschapsbeoefening anderzijds? In paragraaf 4 volgt de conclusie.

\section{Juridisch kader}

\subsection{Uitgangspunten}

Vooropstaat dat bij een individu niet zonder diens toestemming lichaamsmateriaal mag worden afgenomen en dat hij zeggenschap heeft over wat er met vrijgekomen persoonsgegevens en lichaamsmateriaal gebeurt. Die uitgangspunten zijn terug te voeren op het - in het recht op bescherming van de persoonlijke levenssfeer (artikel 10 Grondwet) en het recht op lichamelijke integriteit (artikel 11 Grondwet) verankerde - principe van zelfbeschikking. Overigens gaat het hierbij niet om absolute zelfbeschikking: omwille van het algemeen belang of belangen van derden kunnen aan zelfbeschikking - door wetgever of rechter - grenzen worden gesteld..$^{5}$ Zo vormt het belang van kennisvermeerdering via wetenschappelijk onderzoek een legitieme grond om de zeggenschap van patiënten over hun gegevens en lichaamsmateriaal te beperken. ${ }^{6}$

Bijzonder aan de situatie na overlijden is dat de overledene ophoudt een 'persoon' te zijn. Het lichaam verandert in een 'lijk' of 'stoffelijk overschot'. Omdat iemands juridische persoonlijkheid door het overlijden verloren gaat, heeft de betrokkene na zijn dood geen subjectieve rechten meer. ${ }^{7}$ Dit alles betekent echter niet dat de overledene geen rechtsbescherming meer geniet. Zo kan hij bij leven bepalen wat er na overlijden met zijn gegevens en lichaamsmateriaal gebeurt en welke bestemming zijn stoffelijk overschot krijgt. Persoonlijkheidsrechten waarover mensen bij leven beschikken, werken door na overlijden. ${ }^{8}$ De rechtsbescherming na de dood is terug te voeren op enerzijds het recht op geheimhouding dat in beginsel na overlijden zijn betekenis behoudt en anderzijds (de doorwerking van) de

4 Onderzoek met foetaal weefsel en met het weefsel van een levensvatbare vrucht wordt in deze bijdrage buiten beschouwing gelaten.

5 M.C. Ploem, Tussen privacy en wetenschapsvrijheid. Regulering van gegevensverwerking voor medisch-wetenschappelijk onderzoek, Den Haag: Sdu Uitgevers 2004, p. 31-37; J.K.M. Gevers, Beschikken over cellen en weefsels, Kluwer: Deventer 1990; E.T.M. Olsthoorn-Heim, Medisch-wetenschappelijk onderzoek. Lichaamsmateriaal voor de wetenschap, Utrecht: VGR 1995, p. 35-38.

6 Zie in dit verband ook de in par. 2.2 te bespreken WGBO-bepalingen inzake het gebruik van persoonsgegevens en (anoniem) lichaamsmateriaal voor medisch-wetenschappelijk onderzoek.

7 N. van Gelder, Commercialisering van menselijk materiaal, Intersentia: Antwerpen/Cambridge 2015, p. 45-50. Hieruit volgt dat overledenen noch personen die hen bij leven vertegenwoordigden zich op in het BW of in andere wetgeving verankerde rechten kunnen beroepen.

$8 \quad$ Zie J.K.M. Gevers, Beschikken over cellen en weefsels, Kluwer: Deventer 1990, p. 10. 
zeggenschap van de overledene over het eigen lichaam en daarvan afgescheiden stoffen of delen. ${ }^{9}$

Welke positie hebben nabestaanden ten aanzien van de overledene? Behoudens het indienen van een klacht of het starten van een juridische procedure, is hun eventuele rol die zij in het kader van de behandeling van de overledene vervulden in principe uitgespeeld. ${ }^{10}$ Niettemin zal het lijk van hun dierbare en alles wat daarover bekend of afkomstig is, voor hen grote (emotionele) betekenis hebben; het is direct verbonden met de nagedachtenis aan de overledene. Uit piëteit met de nabestaanden is in veel rechtsstelsels, zo ook het Nederlandse, bepaald dat ze het lichaam van hun dierbare een bestemming mogen geven ('bestemmingsrecht'). ${ }^{11}$ Dat recht impliceert geenszins dat nabestaanden over het lijk of daarvan afgescheiden delen kunnen beschikken. Integendeel: zij mogen alleen over de wijze van lijkbezorging beslissen voor zover de overledene dat niet zelf heeft gedaan, en dan nog geldt dat ze de vermoedelijke wil van de overledene zo veel mogelijk moeten respecteren. De opvatting dat de eigendom van het lijk of daarvan afgescheiden delen na overlijden van een persoon overgaat op diens nabestaanden, zoals door een nabestaande in een recente tuchtzaak werd gesteld, ${ }^{12}$ is dus onjuist.

\subsection{Wetenschappelijk onderzoek met gegevens}

\subsubsection{Onderzoek met gegevens die bij leven beschikbaar zijn gekomen}

Welke regels gelden indien men onderzoek wil doen met in het patiëntendossier bewaarde gegevens van overledenen? Voorop staat dat de WGBO niet meer geldt indien de betrokkene is overleden; dat laat echter onverlet dat artikel 7:457 eerste lid en artikel 7:458 BW kunnen worden gezien als de concretisering van het medisch beroepsgeheim, dat na overlijden doorwerkt. Uit artikel 7:457 eerste lid BW kan worden afgeleid dat onderzoek met medische gegevens van overledenen is toegestaan indien de betrokkene of diens vertegenwoordiger hiervoor bij leven toestemming heeft gegeven. Dit uitgangspunt is echter niet absoluut. Als bij leven geen toestemming van de betrokkene (of diens vertegenwoordiger) is verkregen, mogen de betreffende - tot individuele personen te herleiden ${ }^{13}$ - gegevens toch voor onderzoek worden gebruikt indien aan bepaalde voorwaarden is voldaan. In het

9 J.K.M. Gevers, 'Rechtsbescherming na de dood', in: J.K.M. Gevers en J.H. Hubben (red.), Grenzen aan de zorg; zorgen aan de grens, Alphen aan den Rijn: Samsom H.D. Tjeenk Willink 1990, p. 170.

10 Zie echter Hof Amsterdam 29 januari 1998, TvGR 1998/34, waarin aan een ex-mentor een zelfstandig inzagerecht in het dossier van de overledene werd toegekend.

11 N. van Gelder, Commercialisering van menselijk materiaal, Intersentia: Antwerpen/Cambridge 2015, p. 51.

12 Zie CTG 8 maart 2016, ECLI:NL:TGZCTG:2016:107. In deze zaak klaagde een zoon over het feit dat het ziekenhuis het weefsel van zijn overleden moeder niet aan de familie had overhandigd.

13 Onderzoek met 'anonieme' gegevens valt niet onder de privacywetgeving en men is zonder meer vrij dat uit te voeren, ook als de betrokkene overleden is. Wel moet men zich realiseren dat van daadwerkelijke anonimiteit niet snel sprake is. 'Anoniem' wil zeggen dat de betreffende gegevens alleen door een onevenredige inzet van tijd, menskracht en middelen tot een patiënt te herleiden zijn. Zogenaamd 'twee-weg-coderen' (naam, geboortedatum, patiëntnummer e.d. worden vervangen door een willekeurig gekozen code, maar kunnen via een 'codesleutel' - indien nodig - worden achterhaald) is in principe onvoldoende om gegevens te anonimiseren in de zin van de privacywetgeving. Zie in die zin ook de opinie van de EU-art. 29 werkgroep (adviesorgaan van nationale dataprotectie-toezichthouders) uit 2007 over persoonsgegevens, p. 16. en M.C. Ploem, Gegeven voor de wetenschap. Onderzoek met gegevens, lichaamsmateriaal en biobanken, Preadvies voor de Vereniging voor Gezondheidsrecht, Utrecht: VGR 2010, p. 137-138. 
licht van artikel 7:458 BW komen die erop neer dat het vragen van toestemming in redelijkheid niet meer mogelijk is (hetgeen hier per definitie het geval is) of niet kan worden verlangd, ${ }^{14}$ dat de persoonlijke levenssfeer van de betrokkene niet onevenredig wordt geschaad, dat het onderzoek een algemeen belang dient en niet zonder de betreffende gegevens kan worden uitgevoerd, en dat de betrokkene (of diens vertegenwoordiger) bij leven over de mogelijkheid van onderzoek met zijn gegevens is geïnformeerd en daartegen niet uitdrukkelijk bezwaar heeft gemaakt.

Het kan echter ook gaan om onderzoek met gegevens die niet in het kader van de reguliere zorgverlening, maar in de context van onderzoek met proefpersonen in de zin van de Wet medisch-wetenschappelijk onderzoek met mensen (WMO) zijn verzameld. In principe kunnen onderzoekers de gegevens van proefpersonen ook na hun overlijden voor het onderzoek in kwestie (blijven) gebruiken omdat zij (of hun vertegenwoordigers) - op grond van artikel $6 \mathrm{WMO}$ - reeds schriftelijk met onderzoeksdeelname, inclusief het gebruik van de tijdens het onderzoek verzamelde gegevens, hebben ingestemd. Als die toestemming door de vertegenwoordiger is gegeven, kan deze op ieder moment door hem worden ingetrokken, ook na overlijden van de proefpersoon. Langs die weg kan dan alsnog door de vertegenwoordiger worden bepaald dat de tot dan toe verzamelde gegevens (voor zover redelijkerwijs mogelijk) moeten worden vernietigd of geanonimiseerd.

Tot slot aandacht voor een bijzondere situatie binnen het proefpersonenonderzoek: het uitvoeren van onderzoek in een noodsituatie. Dat mag in beginsel ook zonder toestemming van de proefpersoon of diens vertegenwoordiger, althans voor zover het onderzoek de betrokkene ten goede kan komen (zie artikel 6 vierde lid WMO). Het komt voor dat de proefpersoon overlijdt voordat er gelegenheid is geweest om hemzelf of de vertegenwoordiger om toestemming voor deelname te vragen. De vraag rijst dan of respectievelijk onder welke voorwaarden de tijdens het onderzoek verzamelde gegevens voor het onderzoek mogen worden gebruikt. Hierover kan verschillend worden gedacht. Gesteld kan worden dat door het overlijden van de proefpersoon zijn deelname aan het onderzoek stopt en dat er dus in dat verband geen rol meer is weggelegd voor de vertegenwoordiger(s) van de proefpersoon. Uit een dergelijke zienswijze volgt overigens ook dat er juridisch geen grondslag meer is om de reeds verzamelde gegevens van de betrokkene voor het onderzoek te blijven gebruiken, tenzij artikel 7:458 BW op deze situatie van overeenkomstige toepassing zou kunnen worden geacht. In dat geval zouden de inmiddels verzamelde onderzoekgegevens voor het onderzoek kunnen worden gebruikt tenzij de betrokkene bij leven in algemene zin tegen het gebruik van zijn medische gegevens voor onderzoek bezwaar heeft gemaakt.

Men kan echter ook redeneren dat het overlijden van de proefpersoon niet zonder meer betekent dat hij niet langer aan het onderzoek kan deelnemen. Het spreekt vanzelf dat na de dood geen interventies meer bij de proefpersoon mogen worden uitgevoerd, maar daarmee is niet gezegd dat de tijdens het onderzoek beschikbaar gekomen gegevens (en lichaamsmaterialen) niet meer voor het onderzoek zouden mogen worden gebruikt. Die zijn immers op basis van artikel 6 vierde lid WMO rechtmatig verkregen ten behoeve van het betreffende medisch-wetenschappelijk onderzoek. Het ligt dan in de rede dat zo spoedig mogelijk toestemming aan de nabestaanden wordt gevraagd. 


\subsubsection{Onderzoek met gegevens die na overlijden beschikbaar komen}

Via een verklaring van natuurlijk overlijden ${ }^{15}$ doet de behandelend arts opgave van de doodsoorzaak van de overledene en van de gegevens die daarmee onmiddellijk samenhangen (artikel 12a eerste lid Wlb). Deze gegevens zijn bedoeld voor de overheidsstatistiek, een taak die is belegd bij het Centraal Bureau voor de Statistiek (CBS). ${ }^{16}$ De arts vermeldt op het zogenaamde 'B-formulier' de ziekte die rechtstreeks tot de dood heeft geleid (bijvoorbeeld longontsteking) alsmede de aandoening(en) die aan de doodsoorzaak ten grondslag heeft (hebben) gelegen of daaraan heeft (hebben) bijgedragen (bijvoorbeeld hartfalen of kanker). Het doodsoorzakenformulier wordt in een gesloten enveloppe, met daaraan bevestigd een strook met de identiteitsgegevens van de overledene, gestuurd naar de ambtenaar van de burgerlijke stand, die de enveloppe zonder aangehechte strook doorstuurt naar het CBS. ${ }^{17}$ Het doodsoorzakenregister is in beginsel uitsluitend bedoeld voor de activiteiten van het $\mathrm{CBS},{ }^{18}$ maar wordt ook door de medische onderzoekswereld als een waardevolle informatiebron gezien. De wetgever heeft zich daarvan rekenschap gegeven en in (artikel 42a van) de Wet op het Centraal bureau voor de statistiek (Wet CBS) bepaald dat de directeur-generaal van het CBS 'op verzoek, ten behoeve van wetenschappelijk onderzoek op het terrein van de volksgezondheid, gegevens [kan] verstrekken die het CBS ten behoeve van statistisch onderzoek op grond van artikel 12a Wet op de lijkbezorging heeft verzameld, van personen die in een wetenschappelijk onderzoek waren betrokken. De directeur-generaal willigt een verzoek als bedoeld in het eerste lid slechts in, indien de betrokkene tot een zodanige verstrekking zijn uitdrukkelijke toestemming heeft gegeven dan wel, indien de betrokkene tot een zodanige verstrekking geen uitdrukkelijke toestemming heeft kunnen geven, voor zover verzoeker voldoende aantoont dat: a. het vragen van toestemming bij leven van de betrokkene in redelijkheid niet mogelijk was of kon worden gevergd; $b$. niet gebleken is dat de betrokkene bij leven bezwaar heeft gemaakt tegen het verwerken van diens persoonsgegevens ten behoeve van wetenschappelijk onderzoek; c. het onderzoek een algemeen belang dient; $d$. het onderzoek niet zonder de desbetreffende gegevens kan worden uitgevoerd; e. het onderzoek overigens voldoet aan daaraan redelijkerwijs te stellen eisen.'

Tot slot moet nog worden gewezen op de 'Regeling verstrekking gegevens doodsoorzaken CBS' die op 28 augustus 2007 in de Staatscourant verscheen. ${ }^{19}$ Daarin wordt het vereiste van 'uitdrukkelijke toestemming' in artikel 1 eerste lid sub $g$ van de regeling gedefinieerd, en wel als volgt: 'de op een duurzame gegevensdrager vastgelegde toestemming van de betrokkene, die gericht is op het gebruik voor wetenschappelijk onderzoek van de doodsoorzaak'. Als onderzoekers niet kunnen aantonen dat de betrokkenen bij leven toestem-

15 Het begrip 'natuurlijke dood' wordt in de Wlb niet nader gedefinieerd. In de oude wet van 1955 was dit omschreven als 'ieder overlijden ten gevolge van spontane ziekte of ouderdom'. Zie ook J.K.M. Gevers, 'De nieuwe wetgeving inzake lijkbezorging', NTvG 1991, p. 1925-1927.

16 Zie (art. 3) Wet CBS, Stb. 2003, 516.

17 Zie art. 2 Vaststelling formulier opgave doodsoorzaak, besluit van 25 april 2002, Stcrt. 2002, 86, p. 8.

18 Op het CBS rust ex art. 37 Wet CBS een 'geheimhoudingsplicht', dat wil zeggen dat de door het CBS ontvangen gegevens niet aan derden mogen worden verstrekt en alleen zodanig openbaar mogen worden gemaakt dat daaraan geen 'herkenbare gegevens' over individuele personen kunnen worden ontleend. Zie Kamerstukken II 1993/94, 23576, 3, p. 19.

19 Deze werd uitgevaardigd door de staatssecretaris van Economische Zaken; zie Stcrt. 2007, 165, p. 4. 
ming hebben gegeven, zullen ze een beroep moeten doen op de uitzonderingsregeling. Voorts voorziet de regeling in een breed samengestelde commissie die tot taak heeft aan de directeur-generaal van het CBS advies uit te brengen over de aan hem voorgelegde verstrekkingsverzoeken. ${ }^{20}$

\subsection{Wetenschappelijk onderzoek met lichaamsmateriaal}

\subsubsection{Onderzoek met lichaamsmateriaal dat bij leven beschikbaar is gekomen}

Het verrichten van onderzoek met lichaamsmateriaal van overledenen dat voor het overlijden beschikbaar is gekomen, valt gedeeltelijk onder het bereik van de WGBO, en wel onder artikel 7:467 BW. Voor het overige bestaat hiervoor op dit moment geen wetgeving, ofschoon die al meer dan twintig jaar geleden door de regering werd aangekondigd. Artikel 7:467 BW bepaalt dat opgeslagen lichaamsmateriaal in anonieme vorm voor wetenschappelijk onderzoek mag worden gebruikt, tenzij de patiënt van wie het afkomstig is eerder daartegen bezwaar heeft gemaakt. ${ }^{21}$ Mocht de overledene dus bij leven van die bezwaarmogelijkheid gebruik hebben gemaakt, dan mag zijn materiaal - zou het na overlijden nog voor enige tijd voor andere doelen, zoals zorgverlening aan familieleden, worden bewaard - niet meer voor onderzoeksdoeleinden worden aangewend.

Voor onderzoek met niet-anoniem materiaal - waarvan gelet op de interpretatie van het begrip herleidbaarheid in de zin van de privacywetgeving ${ }^{22}$ al snel sprake zal zijn - is er geen wetgeving. De minister van VWS maakte medio 2015 in een brief aan de Tweede Kamer duidelijk daarin verandering te zullen brengen, ${ }^{23}$ maar er circuleert nog steeds zelfs geen concept-wetsvoorstel. Uit het schrijven van de minister blijkt dat de regering voornemens is bij onderzoek met herleidbaar materiaal uit te gaan van een toestemmingssysteem. ${ }^{24}$ In de brief staat dat ' $[\mathrm{h}$ ] et gebruik maken van bijvoorbeeld in een ziekenhuis opgeslagen lichaamsmateriaal zonder toestemming van degene die het materiaal heeft afgestaan (...) aan diens zelfbeschikking [raakt], en aan het vertrouwen dat het materiaal niet voor andere doeleinden wordt gebruikt dan waarvoor het was afgenomen en bewaard. (...) Het raakt aan de belangen die in het medisch beroepsgeheim zijn vastgelegd, en is daarmee verbonden aan de vrije toegang tot zorg. Dit benadrukt het belang van zeggenschap over het lichaamsmateriaal door degene van wie het materiaal afkomstig is.' 25 Overigens blijkt uit de brief ook duidelijk dat toestemming voor wetenschappelijk onderzoek met lichaamsmateriaal geen absolute eis zal zijn: 'Om het maatschappelijke belang van onderzoek naar nieuwe inzichten, technieken en toepassingen in balans te brengen

20 De 'Commissie verstrekking doodsoorzaken CBS' werd in 2007 ingesteld.

21 De regering maakte tijdens de parlementaire behandeling van de WGBO duidelijk dat zij daarbij algemene voorlichting over het gebruik van geanonimiseerde materiaal voor wetenschappelijk onderzoek voor ogen had. Kamerstukken II 1989/90, 21561, 3, p. 50.

22 Zie noot 6.

23 Brief van 30 juni 2015 van de minister van VWS aan de Tweede Kamer inzake wetgeving omtrent zeggenschap lichaamsmateriaal, Kamerstukken II 2014/15, 34000 XVI, 113.

24 Een dergelijk uitgangspunt is ook in de parlementaire behandeling van de WGBO begin jaren 90 terug te vinden; zie Kamerstukken II 1991/92, 21561, 11, p. 52. Wat betreft de regering gaat het hierbij om een globaal toestemmingssysteem, d.w.z. dat toestemming is gebaseerd op algemene informatie over de mogelijkheid van toekomstig gebruik van lichaamsmateriaal voor wetenschappelijk onderzoek.

25 Kamerstukken II 2014/15, 34000 XVI, 113, p. 2. 
met het belang van het individu op zelfbeschikking, is het wenselijk in een wettelijk kader uitzonderingen op het uitgangspunt van zelfbeschikking op te nemen. Wanneer het vragen van toestemming voor zulk nader gebruik in redelijkheid niet mogelijk is of in redelijkheid niet van de onderzoeker kan worden verlangd, zal gebruik onder voorwaarden ook zonder toestemming mogelijk moeten kunnen zijn, mits degene van wie het materiaal afkomstig is daartegen niet bezwaar heeft gemaakt. Op deze wijze kan tegemoet gekomen worden aan de belangen van onderzoekers, zoals die tot op heden verwoord zijn in een door henzelf opgestelde gedragscode ${ }^{26}$ voor onderzoek met lichaamsmateriaal'. ${ }^{27}$

Wat betekent dit alles nu voor wetenschappelijk onderzoek met herleidbaar materiaal van een overledene? Duidelijk is dat de wetgever voornemens is ruimte te creëren voor nader gebruik van lichaamsmateriaal voor de wetenschap waarvoor de betrokkene geen toestemming heeft kunnen geven, bijvoorbeeld omdat deze is overleden voordat dit hem gevraagd kon worden. Wel zal dan - naar analogie van artikel 7:458 BW - een aantal voorwaarden in acht moeten worden genomen, zoals dat het onderzoek een algemeen belang dient respectievelijk niet zonder het betreffende lichaamsmateriaal kan worden uitgevoerd en dat de betrokkene (of diens vertegenwoordiger) bij leven over de mogelijkheid van onderzoek met zijn lichaamsmateriaal is geïnformeerd en daartegen niet uitdrukkelijk bezwaar heeft gemaakt. Of toetsing door een ethische commissie ook een element zal zijn van de aangekondigde uitzonderingsbepaling moet worden afgewacht. Dit laatste zou wel in lijn zijn met internationale documenten, zoals Aanbeveling R (2006) 4 'on research on biological materials of human origin' van de Raad van Europa ${ }^{28}$ en de 'Guidelines on Human Biobanks and Genetic Research Databases' uit 2009 van de Organisatie voor Economische Samenwerking en Ontwikkeling. ${ }^{29}$ De FMWV-gedragscode 'Verantwoord omgaan met lichaamsmateriaal ten behoeve van wetenschappelijk onderzoek' uit $2011^{30}$ hanteert eveneens als uitgangspunt dat ieder onderzoek met herleidbaar lichaamsmateriaal door een ethische commissie moet worden getoetst en goedgekeurd (zie paragraaf 15 van de code).

\subsubsection{Onderzoek met lichaamsmateriaal dat na overlijden beschikbaar komt}

Iemands lichaamsmateriaal kan ook na diens overlijden beschikbaar komen, namelijk bij terbeschikkingstelling van een lijk $\mathrm{k}^{31}$ voor ontleding in het kader van wetenschap of onder-

26 Code 'Verantwoord omgaan met lichaamsmateriaal ten behoeve van wetenschappelijk onderzoek' (2011), www.federa.org. Overigens blijkt uit art. 1 van de code dat deze geen betrekking heeft op materiaal van overledenen. Dit is te begrijpen waar het gaat om onderzoek met lichaamsmateriaal dat na overlijden vrijkomt, maar niet waar het gebruik van restmateriaal van overledenen voor research betreft.

27 Kamerstukken II 2014/15, 34000 XVI, 113, p. 2. In dit verband wordt verwezen naar art. 32 Verklaring van Helsinki van de World Medical Association, laatstelijk gewijzigd te Fortaleza, Brazilië, oktober 2013 ('There may be exceptional situations where consent would be impossible or impracticable to obtain for such research. In such situations the research may be done only after consideration and approval of a research ethics committee') en art. 7:458 BW waarin voor wat betreft het gebruik van gegevens uit het medisch dossier zonder toestemming van de betrokkene voor een soortgelijke benadering is gekozen.

28 Zie art. 22 Aanbeveling R (2006)4.

29 Zie principe 4.B.

30 Zie noot 28.

31 Een 'lijk' is o.g.v. art. 2 lid 1 Wlb 'het stoffelijk overschot van de overledene of doodgeborene'. 
wijs, of door middel van obductie. ${ }^{32}$ De grondslag voor dergelijke activiteiten ligt in de Wlb.

- Het lichaamsmateriaal komt via ontleding beschikbaar

De Wlb onderscheidt naast algemene wijzen van lijkbezorging (begraving en crematie) ook bijzondere vormen. Een daarvan is ontleding in het belang van de wetenschap of het wetenschappelijk onderwijs (artikel $67 \mathrm{Wlb}$ ). ${ }^{33}$ Ontleding is een eindbestemming van het lijk. ${ }^{34} \mathrm{Er}$ is na ontleding geen sprake meer van een lijk, er zijn alleen 'overblijfselen'. Die eindigen uiteindelijk (als ze voor wetenschappelijk onderzoek of onderwijs niet meer nodig zijn) in de afvalverwerking van het laboratorium of ziekenhuis.

Ontleding voor wetenschap of onderwijs is alleen toegestaan als de overledene dit bij leven zo heeft bepaald. Een dergelijke wilsbeschikking is vormvrij. Iemand kan (mits wilsbekwaam en 16 jaar of ouder) zijn wens in een schriftelijke verklaring (notariële akte of eigenhandig geschreven, gedagtekende en ondertekende wilsbeschikking) neerleggen, maar dat hoeft niet. Hij kan zijn lijk ook mondeling tot ontleding voor onderzoek of onderwijs bestemmen. ${ }^{35}$ Als de overledene zijn lijk niet tot ontleding heeft bestemd en er van hem rond de bestemming van zijn lijk geen andere wensen bekend zijn, kan ontleding ook plaatsvinden indien de nabestaanden of, bij ontstentenis of onbereikbaarheid daarvan, degenen die de zorg voor het lijk op zich nemen (zoals de uitvaartonderneming) daarvoor op de voet van artikel 67 derde lid Wlb toestemming geven. ${ }^{36}$ De groep van vertegenwoordigers die het lijk tot ontleding mogen bestemmen is ruim. In eerste instantie mag de partner of levensgezel van de overledene hiertoe besluiten, maar als die er niet is of als die onbereikbaar blijkt, mogen ook de meerderjarige bloed- of aanverwanten tot en met de derde graad, of, wanneer deze niet bereikbaar zijn, de aanwezige meerderjarige erfgenamen of anders degenen die de zorg voor het lijk op zich nemen instemmen met ontleding. Uitgangspunt hierbij is dat degene die daarover besluit zo goed mogelijk de vermoedelijke wil van de overledene reconstrueert. ${ }^{37}$ Dat laatste is overigens alleen mogelijk indien nabestaanden over de belangrijkste aspecten van de ontleding (of de hierna te bespreken obductie) goed geïnformeerd zijn. Hierbij valt te denken aan het exacte doel van de ontleding, hoe lang het lijk of daarvan afgescheiden delen worden bewaard, hoe de privacy van de overledene wordt beschermd, hoe wordt omgegaan met bevindingen uit wetenschappelijk onderzoek die voor de nabestaanden van belang zijn, of de nabestaanden hun toestemming weer kunnen intrekken en wat daarvan de gevolgen zijn. Duidelijk moet ook zijn dat

32 Voor de volledigheid moet hier ook nog worden genoemd het - in het kader van orgaandonatie - beschikbaar komen van voor implantatie ongeschikte organen voor (op implantatie gericht) wetenschappelijk onderzoek. Art. 13 Wet op de orgaandonatie bepaalt dat degene die toestemming verleent voor orgaandonatie hiermee instemt, tenzij deze uitdrukkelijk anders bepaalt. We laten deze specifieke regeling hier verder buiten beschouwing.

33 Zie ook memorie van toelichting op de Wlb: Kamerstukken II 1970/71, 11256, 3.

34 Het lijk is bestemd om in het belang van de wetenschap of het onderwijs geheel of gedeeltelijk te worden verbruikt. Kamerstukken II 1975/76, 11256, 6, p. 23 en Kamerstukken II 1980/81, 11256, 10, p. 9.

35 Kamerstukken II 1981/82, 11256, 17, p. 14. Uit art. 19 Wlb volgt dat toestemming voor ontleding alleen geacht wordt zijn geldigheid te verliezen als de betrokkene deze uitdrukkelijk en specifiek herroept.

36 Als de burgemeester de lijkbezorging op zich neemt, kan het lijk niet tot ontleding worden bestemd. Zie art. 21 lid 1 Wlb.

37 Kamerstukken II 1981/82, 11256, 17, p. 6. 
nabestaanden het lijk of daarvan afgescheiden delen niet kunnen terugvorderen indien ze eenmaal toestemming voor ontleding hebben gegeven.

Voor alle duidelijkheid zij nog opgemerkt dat het vragen van toestemming voor ontleding van het lijk of onderdelen daarvan aan de familieleden voordat de patiënt in kwestie is overleden niet in overeenstemming is met de Wlb. Dit geldt dus ook voor de praktijk van de Nederlandse Hersenbank (NHB) om de vertegenwoordiger van een potentiële (permanent wilsonbekwame) donor voor diens overlijden te vragen of deze namens het wilsonbekwame familielid over hersendonatie voor onderzoek op het terrein van bijvoorbeeld dementie of een bepaalde verstandelijke handicap wil beslissen. De Hersenbank hanteert deze werkwijze overigens niet zonder reden: hersenweefsel gaat na overlijden snel achteruit en onderzoekers trachten op deze manier geen tijd te verliezen. Naar ons oordeel laat het wettelijke kader wel toe dat een vertegenwoordiger enige tijd voor het overlijden van zijn wilsonbekwame familielid op de hoogte wordt gebracht van het belang van terbeschikkingstelling van hersenweefsel en/of de hersenen van zijn dierbare voor onderzoek en hoe de toestemmingsprocedure na overlijden verloopt.

Ontleding dient door of onder toezicht van een arts plaats te vinden en mag pas aanvangen als de burgemeester hiertoe schriftelijk verlof heeft verleend (artikel $68 \mathrm{Wlb}$ ) ${ }^{38}$ en er sinds het overlijden van de betrokkene minstens 36 uur zijn verstreken (artikel $69 \mathrm{Wlb}$ ). Probleem bij ontleding is echter dat de daarvoor noodzakelijke conserverende handelingen ten aanzien van het lijk binnen 36 uur na het overlijden moeten plaatsvinden, dit om te voorkomen dat de ontbinding van het lijk al zover is voortgeschreden dat een goede conservering en bestudering van het weefsel in ernstige mate worden bemoeilijkt. De wetgever heeft dit probleem ondervangen door in artikel 71 tweede lid Wlb te bepalen dat het verbod van conserverende handelingen niet van toepassing is indien het lijk tot ontleding is bestemd.

Tijdens de parlementaire behandeling van de wetsbepaling is door de Tweede Kamer nog geopperd nadere voorschriften te stellen aan de anatomische laboratoria waar de ontledingen plaatsvinden, maar de regering zag daartoe geen noodzaak. Er gelden in die laboratoria interne voorschriften en afspraken over (onder andere) de omgang met gegevens en overblijfselen van ontleding en er waren geen aanwijzingen dat zich in dit verband problemen voordeden. ${ }^{39}$

Tot slot aandacht voor een bijzondere kwestie, namelijk of de oprichting van een zogenaamde biologisch-forensische testlocatie ('body farm') - in Nederland vooralsnog niet aan de orde - ook als ontleding van een lijk voor de wetenschap kan worden beschouwd. ${ }^{40}$ Zo'n testlocatie strekt ertoe factoren te bestuderen die na de dood - onder verschillende omstandigheden - van invloed zijn op de ontbinding van het menselijk lichaam. Hierdoor

Deze extra eis bij ontleding van een lijk waarborgt dat niet strijdig met de strekking van de wet wordt gehandeld. Het verlof van de burgemeester moet op uiterlijk de derde dag na overlijden zijn afgegeven. Het vermeldt ook de plaats van ontleding; op die manier kan de burgemeester slechts verlof verlenen voor ontledingen op plaatsen waar aannemelijk is dat dit op een verantwoorde wijze plaatsvindt (Kamerstukken II 1980/81, 11256, 10, p. 7).

39 Kamerstukken II 1975/76, 11256, 6, p. 23; Kamerstukken II 1981/82, 11256, 17, p. 14.

40 Dergelijke testlocaties zijn vooralsnog alleen in de Verenigde Staten operationeel, waarbij die van de University of Tennessee in Knoxville de oudste en bekendste is. Zie website Forensic Anthropology Center, web.utk.edu/ fac/default.html. Zie hierover ook: H. Croonen, 'Bewijs op het lijf', Medisch Contact 2011-16, p. 984-985. 
kunnen nieuwe inzichten op bijvoorbeeld het terrein van slachtofferidentificatie en het vaststellen van de doodsoorzaak worden opgedaan. Hiervoor ter beschikking gestelde lichamen worden in de buitenlucht begraven en na verloop van tijd weer opgegraven. Een belangrijk verschil tussen de gebruikelijke ontledingspraktijk in het laboratorium en de ontbindingspraktijk in de open lucht is dat bij deze laatste vorm van 'ontleding' eerder sprake kan zijn van maatschappelijke onrust of overlast voor de omgeving, zoals drukte door sensatiezoekers of stankoverlast door het ontbindingsproces. Aan dergelijke factoren mag uiteraard niet voorbij worden gegaan, maar ze betekenen onzes inziens niet dat artikel $67 \mathrm{Wlb}$ geen basis zou kunnen bieden voor het laten ontbinden van lijken op een testlocatie. Het gaat hierbij immers evengoed om wetenschappelijk onderzoek met het stoffelijk overschot en de restanten van het lijk eindigen uiteindelijk net als de overblijfselen na ontleding in de afvalverwerking van het onderzoeksinstituut. Wel heeft de instelling die verantwoordelijk is voor de testlocatie ook met andere wetgeving dan de Wlb te maken, zoals de milieuwetgeving.

- Het lichaamsmateriaal komt via obductie beschikbaar

Bij obductie of sectie (die moet worden uitgevoerd door een arts) gaat het om gedeeltelijke ontleding van het lijk, anders gezegd, aldus de memorie van toelichting op de oorspronkelijke (in 1971 tot stand gekomen) wettekst, om '(...) het openen van een lijk teneinde de doodsoorzaak te kunnen verifiëren, in de regel door middel van een pathologisch-anatomisch, toxicologisch of bacteriologisch onderzoek'. ${ }^{41}$ Er zijn twee belangrijke verschillen met de situatie van ontleding ex artikel $67 \mathrm{Wlb}$. Het eerste is dat het bij obductie niet gaat om een bijzondere vorm van lijkbezorging; het lijk wordt na sectie gewoon begraven of gecremeerd. ${ }^{42}$ Het tweede is dat obductie naar de letter van de wet plaatsvindt om de doodsoorzaak op te helderen en dus niet - zoals bij ontleding in de zin van artikel $67 \mathrm{Wlb}$ - bedoeld is om wetenschappelijk onderzoek en onderwijs in algemene zin mogelijk te maken. Hierbij zij aangetekend dat de minister in 2014 wel duidelijk maakte dat obductie in haar visie meerdere doelen kan dienen: 'Het kan inzicht geven in (erfelijke of infectieuze) factoren die een rol hebben gespeeld bij het ontstaan of beloop van een ziekte bij de overledene, en kan daarmee van belang zijn voor de nabestaanden zelf. Het uitvoeren van obductie is ook een middel om terug te kijken op de verleende zorg, en zo te kunnen bezien of en welke verbeteringen daarbij in het vervolg mogelijk zijn. Tot slot wordt de kennis over ziekten ermee vergroot. Het is daarmee een belangrijk middel om kwaliteit en kennis in de zorg te waarborgen en vergroten. ${ }^{43}$

Het voorafgaande heeft gevolgen voor de positie van de nabestaanden. Hebben die bij kennisname van de uitkomsten van in het kader van een ontleding uitgevoerd wetenschappelijk onderzoek in principe geen belang, ${ }^{44}$ bij sectie ligt dit anders indien deze mede wordt

41 Kamerstukken II 1970-1971, 11256, 3.

42 Tegen die achtergrond kan ook de burgemeester het lijk tot sectie bestemmen, hetgeen bij ontleding, zoals hiervoor, in noot 38, al werd aangegeven, niet mogelijk is.

43 Zie p. 2 van de brief van de minister van VWS uit 2014 ter beantwoording van Kamervragen over de informatievoorziening rond de obductiepraktijk in ziekenhuizen, Kamerstukken II 2013/14, 30696, 38.

44 Tenzij hieruit iets naar voren komt waarvoor familieleden o.g.v. de 'waarschuwingsplicht' moeten worden geïnformeerd. Zie J.C.J. Dute \& M.C. Ploem, 'Medisch beroepsgeheim en familieleden', TvGR 2013, p. 734-735. 
uitgevoerd om een erfelijke aandoening of besmettelijke ziekte bij de overledene uit te sluiten. ${ }^{45}$ Het verslag van de obductie valt overigens onder het medisch beroepsgeheim en is in beginsel voor hen niet toegankelijk. Zijn er in het verslag echter aanwijzingen dat bepaalde familieleden daadwerkelijk gezondheidsrisico's lopen, dan mogen dergelijke aanwijzingen via de constructie van de 'veronderstelde toestemming' (als de patiënt zich over inzage in zijn dossier na overlijden had kunnen uitlaten, had hij hiervoor zo goed als zeker toestemming verleend) in algemene bewoordingen aan hen worden meegedeeld. ${ }^{46}$

Net als bij volledige ontleding geldt dat obductie in beginsel alleen mag plaatsvinden wanneer de overledene daarvoor bij leven toestemming heeft gegeven. ${ }^{47}$ Indien dat niet is gebeurd (hetgeen bij onverwacht/acuut overlijden veelal het geval zal zijn), kunnen - net als bij ontleding - de nabestaanden ${ }^{48}$ of, wanneer deze er niet meer zijn of onbereikbaar zijn, ${ }^{49}$ degenen die de zorg voor het lijk op zich nemen alsnog toestemming verlenen. In bepaalde situaties kan ook een bevel van een gerechtelijke autoriteit of een verzoek van de hoofdinspecteur van de Inspectie voor de Gezondheidszorg of de voorzitter van de Onderzoeksraad voor Veiligheid tot sectie leiden. Ook voor postmortale radiologie, ook wel virtuele sectie genoemd, waarbij het lijk in principe geheel intact kan blijven, is op de gewone wijze toestemming nodig. ${ }^{50}$

In 2014 kwam (via tv-programma Zembla) naar voren dat de informatievoorziening voor nabestaanden in verband met het vragen van toestemming voor obductie soms te wensen overlaat. Over dit probleem werden ook Kamervragen gesteld. De minister wijst in haar beantwoording op het belang van voldoende en gepaste informatieverstrekking om een goede besluitvorming door de nabestaanden te kunnen waarborgen, maar acht nadere richtlijnen niet nodig, gelet op het feit dat er op dit vlak al voldoende waarborgen en handvatten voorhanden zijn. ${ }^{51}$

Last but not least zij er nog op gewezen dat artikel $72 \mathrm{Wlb}$ niet toelaat dat in toekomstig wetenschappelijk onderzoek 'nader gebruik' plaatsvindt van tijdens obductie vrijgekomen lichaamsmaterialen of onderdelen. Hoewel dat in de praktijk veelvuldig lijkt voor te komen, biedt de betreffende wetsbepaling daartoe geen grondslag. De strekking van de

Sectie kan ook louter op verzoek van de nabestaanden worden uitgevoerd, maar de arts is bij een dergelijke wens niet verplicht de sectie uit te voeren. De kosten zijn in zo'n geval voor rekening van de nabestaanden.

46 J.K.M. Gevers, 'Rechtsbescherming na de dood', in: J.K.M. Gevers \& J.H. Hubben (red.), Grenzen aan de zorg; zorgen aan de grens, Alphen aan den Rijn: Samsom H.D. Tjeenk Willink 1990, p. 172.

47 Net als bij ontleding van het lijk is toestemming niet aan een bepaalde vorm gebonden: het mag mondeling, maar ook via een wilsverklaring.

48 Zie art. 72 lid $2 \mathrm{Wlb}$ dat dezelfde volgorde aangeeft als art. $67 \mathrm{lid} 3 \mathrm{Wlb}$ (zie noot 37). De regering gaf tijdens de parlementaire behandeling aan dat '(...) de meerderjarige kinderen van de overledene eerder in aanmerking komen voor het vragen van toestemming dan de ouders. Indien deze kinderen toestemming hebben verleend of geweigerd, behoeft die van de ouders niet meer te worden gevraagd. Mocht tussen de kinderen casu quo tussen de ouders verschil van mening bestaan, dan kan niet van toestemming in de zin van de wet worden gesproken'. Kamerstukken II 1975/76, 11256, 6, p. 24-25.

49 Van onbereikbaarheid is sprake indien er ondanks herhaalde pogingen geen contact mogelijk is. Kamerstukken II 1975/76, 11256, 6, p. 24.

50 Zie hierover W. Venderink \& J.C.J. Dute, Juridische aspecten van postmortale radiologie, verschijnt binnenkort.

51 Kamerstukken II 2013/14, 30696, 38. De minister wijst op de folder die door de Nederlandse Vereniging Voor Pathologie (NVVP) in samenwerking met de Nederlandse Patiënten en Consumenten Federatie (NPCF) is ontwikkeld. De folder geeft informatie aan nabestaanden over de mogelijkheid en het belang van obductie, welke gevolgen het uitvoeren van obductie kan hebben en welke rol de nabestaande heeft. 
Wlb, casu quo artikel 72, lijkt ons te zijn dat de bij obductie vrijgekomen organen en weefsels na de obductie in het lichaam van de overledene worden teruggeplaatst of, als dat niet mogelijk is, worden vernietigd.

\section{Beschouwing}

Wetenschappelijk onderzoek met (onderdelen van) het lijk of met cellen en weefsels van de overledene is zeker geen onderwerp dat door de wetgever volledig over het hoofd is gezien. Wel is een aantal aspecten van onderzoek na overlijden ongeregeld gebleven.

In dit verband is allereerst te wijzen op het ontbreken van (meermaals door de regering toegezegde) regels inzake zeggenschap over lichaamsmateriaal. Aan dergelijke regels is niet alleen bij leven van de patiënt, maar ook na diens overlijden grote behoefte. Bij leven afgenomen cellen en weefsels kunnen, zo blijkt ook uit de in de inleiding geschetste casus, nog vele jaren na iemands overlijden van grote waarde zijn voor wetenschappelijk onderzoek. Dit laatste wordt nog eens versterkt door een toename van onderzoek op het terrein van de genomics; daarbij gaat het in hoofdzaak om het zoeken naar oorzaken van ziekten en het beloop ervan, alsmede naar de werking en bijwerkingen van geneesmiddelen en andere therapieën. Door het uitblijven van de toegezegde wetgeving blijft een belangrijk punt van discussie onder welke voorwaarden herleidbaar lichaamsmateriaal van een overledene (dat bijvoorbeeld in de archieven van het ziekenhuis wordt bewaard) voor wetenschappelijk onderzoek mag worden gebruikt. Is dit, zoals de gedragscode van de FMWV uit 2011 bepaalt, in principe toegestaan als het lichaamsmateriaal gecodeerd voor onderzoek beschikbaar is en de betrokkene daartegen geen bezwaar heeft gemaakt? Of moet uitgangspunt zijn dat de betrokkene daarvoor bij leven toestemming heeft gegeven? En als dat laatste het uitgangspunt is, is er dan nog ruimte, en zo ja onder welke voorwaarden, het materiaal na overlijden te gebruiken indien de betrokkene die toestemming niet heeft gegeven? En wat is in die situatie de positie van familieleden: hebben die dan namens de overledene nog iets te zeggen over het gebruik van diens lichaamsmateriaal voor wetenschappelijk onderzoek?

Als artikel 7:458 BW als uitgangspunt wordt genomen (de uitzonderingsbepaling die het gebruik van gegevens voor wetenschappelijk onderzoek zonder toestemming van de betrokkene mogelijk maakt), luidt het antwoord op laatstgenoemde vraag ontkennend. De nabestaande verkeert op grond van deze regeling niet in de positie om namens de overledene over het postume gebruik van zijn medische gegevens te beslissen; onderzoekers mogen hiervan - mits op zorgvuldige wijze - gebruik maken als de betrokkene niet expliciet heeft aangegeven daartegen bezwaar te hebben. Er valt, mede vanwege het belang van het kunnen doen van onderzoek en het genereren van nieuwe kennis, veel voor te zeggen die lijn ook bij nader gebruik van restmateriaal van overleden patiënten voor wetenschappelijk onderzoek te volgen. Een probleem is echter wel dat de familieleden dan ook niet meer kunnen worden geïnformeerd over het feit dat uit het onderzoek bevindingen naar voren kunnen komen die voor henzelf van belang kunnen zijn en die in bepaalde gevallen ook aan hen moeten worden meegedeeld ('waarschuwingsplicht'). De kans dat zulke voor bloedverwanten van belang zijnde bevindingen uit onderzoek naar voren komen is het grootst wanneer het gaat om wetenschappelijk onderzoek op het terrein van de genetica. Een voorbeeld is het gebruik van lichaamsmateriaal van plotseling aan een hartstilstand 
overleden patiënten voor onderzoek naar de erfelijke oorzaken hiervan. Als de onderzoeker de bloedverwanten in een dergelijke situatie wel om toestemming zou vragen of hen op zijn minst over het voorgenomen wetenschappelijk gebruik zou informeren (met de mogelijkheid om hiertegen bezwaar te maken), wordt voorkomen dat hij (of de behandelend arts van de nabestaanden) later in de situatie belandt dat hij ze onverwacht (en mogelijk zelfs tegen hun wens in) moet wijzen op een erfelijk risico op eenzelfde dood. Bij het vormgeven van regels voor nader gebruik van lichaamsmateriaal (en wellicht ook nader gebruik van - mogelijk even informatieve - DNA-codes) van overledenen zal, mede in het licht van de snelle toename van onderzoek op het terrein van de genetica, met deze problematiek rekening moeten worden gehouden.

Een tweede belangrijke lacune van het normatieve kader is dat de regeling inzake obductie alleen de ontleding van het lijk in het kader van het vaststellen van de doodsoorzaak regelt en niet het nader gebruik van tijdens obductie vrijgekomen lichaamsmateriaal voor wetenschappelijk onderzoek. Gevers stelde hierover reeds in 1990 het volgende: 'Waar het mij (...) om gaat is dat de sectie in het kader van de wet bedoeld is als een diagnose-post-mortem, een verificatie van de doodsoorzaak in het belang van de wetenschap of ter toetsing van het medisch handelen. Ook in het wetsontwerp [van de Wlb] heeft de sectie die beperkte betekenis. In de praktijk wordt die doelstelling vaak ruimer genomen en wordt door obductie verkregen materiaal ook gebruikt voor wetenschappelijk onderzoek dat geen functie meer heeft in het kader van de na-diagnostiek. Wil men die ruimere praktijk bestendigen, dan is gewenst dat men haar een adequate wettelijke grondslag geeft, met name voor zover zij niet berust op een voorafgaande toestemming van de overledene. ${ }^{.52}$ Die conclusie gaat nog onverminderd op.

Het ruimere gebruik van obductiemateriaal voor ander wetenschappelijk onderzoek dan gericht op de directe doodsoorzaak ontbeert een wettelijke basis en het is de hoogste tijd dat de wetgever daarin verandering brengt. Dit is te meer van belang nu de FMWVgedragscode uit 2011 inzake wetenschappelijk onderzoek met lichaamsmateriaal voor wetenschappelijk onderzoek niet op de situatie na overlijden van toepassing is.

Waaruit dient zo'n 'wettelijke basis' te bestaan? Wij denken hierbij niet alleen aan de eis dat, als de betrokkene zich bij leven over bedoeld gebruik niet specifiek heeft uitgelaten, de nabestaanden hiervoor toestemming moeten geven, maar ook aan een aantal andere voorwaarden, vergelijkbaar met die van artikel 7:458 BW (het onderzoek dient een algemeen belang; het onderzoek kan niet zonder het lichaamsmateriaal worden uitgevoerd; het materiaal wordt niet of indirect herleidbaar opgeslagen; de overledene heeft bij leven geen bezwaar gemaakt tegen nader gebruik van zijn lichaamsmateriaal voor wetenschappelijk onderzoek). Of wetenschappelijk onderzoek met obductiemateriaal ook medisch-ethische toetsing behoeft, is een andere vraag. Nu de betrokkene bij leven niet zelf toestemming heeft gegeven (of heeft kunnen geven), en er bovendien rekening moet worden gehouden met de belangen van nabestaanden in de zin dat er uit onderzoek mogelijk ook belangrijke bevindingen voor bloedverwanten naar voren kunnen komen, is voor een dergelijke voorwaarde veel te zeggen. Daar komt bij dat deze voorwaarde ook al geldt voor nader gebruik van lichaamsmateriaal voor wetenschappelijk onderzoek bij leven (op grond van de FMWV-gedragscode). 
Bij ontleding van het lijk voor wetenschappelijk onderzoek op grond van artikel $67 \mathrm{Wlb}$ speelt niet het probleem dat er geen rechtsgrondslag is, maar wel dat, afgezien van toestemming van de betrokkene of diens nabestaanden, geen nadere voorwaarden worden gesteld. Hier zou natuurlijk ook moeten worden geëist dat het uitgevoerde onderzoek een algemeen belang dient, dat alleen het voor het onderzoek noodzakelijke lichaamsmateriaal wordt benut en dat met het geanalyseerde materiaal en de daaruit afgeleide gegevens zorgvuldig wordt omgegaan.

Verder merken we nog het volgende op. Wat opvalt is dat de familieleden over het uitvoeren van wetenschappelijk onderzoek met het lijk of onderdelen daarvan aanzienlijk meer te zeggen hebben dan over onderzoek met restmateriaal en medische gegevens van hun dierbare. Zij kunnen het lijk van hun overleden familielid bestemmen voor wetenschappelijk onderzoek als deze daar zelf niets over heeft bepaald en vice versa: zij kunnen sectie of obductie weigeren als er over de wensen van de overledene hieromtrent niets bekend is. Dat de familie bij het beschikbaar komen van lichaamsmateriaal na overlijden een sterkere positie heeft vinden wij in het licht van de in paragraaf 2 naar voren gebrachte overwegingen (de gang van zaken rondom het overlijden heeft grote emotionele betekenis voor de familie en is direct verbonden met de nagedachtenis aan de overledene) goed te verdedigen. Er zou alleen aanleiding zijn het indertijd door de wetgever gekozen toestemmingssysteem opnieuw tegen het licht te houden als het wetenschappelijk onderzoek onder de huidige regels ernstig te lijden zou hebben, maar daar lijkt vooralsnog geen sprake van te zijn.

\section{Conclusie}

De regulering van het gebruik van gegevens en lichaamsmateriaal voor medisch-wetenschappelijk onderzoek nadat de patiënt is overleden, vertoont lacunes. Onderscheid moet daarbij worden gemaakt tussen gegevens c.q. lichaamsmateriaal die/dat bij leven beschikbaar zijn/is gekomen en gegevens c.q. lichaamsmateriaal die/dat na overlijden beschikbaar zijn/is gekomen.

Voor gebruik in het kader van medisch-wetenschappelijk onderzoek van gegevens die bij leven beschikbaar zijn gekomen, wijzen artikel 7:457 eerste lid en artikel 7:458 BW de weg. Voor gegevens die na overlijden beschikbaar komen, is het doodsoorzakenregister van belang. De daarin opgeslagen gegevens zijn voor wetenschappelijk onderzoekers slechts beperkt toegankelijk. De bij leven gegeven toestemming staat voorop, met een uitzonderingsregeling die sterk verwant is aan artikel 7:458 BW.

Voor gebruik voor medisch-wetenschappelijk onderzoek van lichaamsmateriaal - zowel het lichaamsmateriaal dat bij leven als het lichaamsmateriaal dat na overlijden beschikbaar is gekomen -wordt een toegespitste regeling node gemist. Een dergelijke regeling heeft de regering in de afgelopen twintig jaar al diverse malen aangekondigd. Niet duidelijk is waarom dat wetgevingstraject niet van de grond komt. De beoogde wet zou voor wat betreft het medisch-wetenschappelijk onderzoek kunnen voortborduren op de regeling van het BW: voor niet-herleidbaar lichaamsmateriaal een geen-bezwaarsysteem, voor herleidbaar lichaamsmateriaal de toestemming als uitgangspunt en een uitzonderingsregeling in de trant van artikel 7:458 BW. Aandacht verdient daarbij wel de positie van nabestaan- 
den, omdat uit het onderzoek bevindingen naar voren kunnen komen die voor hen van belang zijn en waarover zij in bepaalde gevallen moeten worden geïnformeerd.

$\mathrm{Na}$ overlijden zijn van belang de ontleding van het lijk in het belang van wetenschap of onderwijs alsmede de obductie. De obductie wordt uitgevoerd om de doodsoorzaak op te helderen, niet voor wetenschappelijk doeleinden. Daarvoor zou naar ons oordeel een wettelijke basis moeten worden gecreëerd, waarin wordt vastgelegd dat de betrokkene zelf of (tenzij de betrokkene bezwaar heeft gemaakt) diens nabestaanden hiervoor toestemming moeten hebben gegeven. Daarnaast zou de wet in dit kader nadere voorwaarden moeten stellen, zoals de eis dat het onderzoek een algemeen belang dient, de eis dat het onderzoek zonder het betreffende lichaamsmateriaal niet kan worden uitgevoerd en regels voor de vorm waarin het lichaamsmateriaal wordt opgeslagen. Ook dient onderzoek met obductiemateriaal aan medisch-ethische toetsing te worden onderworpen. Dergelijke nadere voorwaarden zouden ook in de wet moeten worden opgenomen voor ontleding van het lijk in het belang van de wetenschap. 